UDC 614.72:616.2/8-053.2

DOI: $10.21668 /$ health.risk/2019.2.06.eng

\title{
ASSESSING RISKS OF RESPIRATORY ORGANS DISEASES AND CO-MORBID PATHOLOGY IN CHILDREN CAUSED BY AMBIENT AIR CONTAMINATION WITH TECHNOGENIC CHEMICALS (COHORT STUDY)
}

\author{
O.A. Maklakova ${ }^{1,2}$ \\ ${ }^{1}$ Federal Scientific Center for Medical and Preventive Health Risk Management Technologies, 82 Monastyrskaya Str., \\ Perm, 614045, Russian Federation \\ ${ }^{2}$ Perm State University, Россия, 15 Bukireva Str., Perm, 614990, Russian Federation
}

\begin{abstract}
We conducted a cohort study which included 144 children who were divided into 3 groups. The test group A was made up of 47 children who lived on a territory where ambient air was contaminated with benzene, phenol, formaldehyde, and particulate matter. The test group B included 45 children exposed to aerogenic introduction of metals (vanadium and manganese). The reference group was made up of 22 children who lived on a territory which was safe in terms of its sanitary-hygienic state.

It was detected that $87.2 \%$ children aged 4-6 who were exposed to aerogenic impacts by benzene, phenol, formaldehyde, and particulate matter had allergic rhinitis, and two thirds of children with respiratory organs diseases had secondary immune failure. By the first school year, probability of allergic rhinitis, bronchial asthma, recurrent bronchitis and functional pathologies in the gastrointestinal tract grew by 4.6-7.9 times. When children reached 11-14 years, frequency of chronic diseases in the gastrointestinal tract among them grew by 14.5 times, and probability of secondary immune failure and disorders in the vegetative nervous system was 6.0-6.6 times higher.

It was noted that ambient air contamination with metals resulted in chronic diseases in the lymphoid tissue of the nasopharynx diagnosed in $65.8 \%$ children; children who were exposed to metals in ambient air ran 1.9 times higher risks of combined pathologies in their respiratory organs and the nervous system. When children reached 7-10 years, probability of allergic rhinitis, pathologies in the lymphoid tissue of the nasopharynx, and functional disorders in the digestive system was 3.9-5.3 times higher. Senior schoolchildren who suffered from chronic respiratory organs diseases ran 2.7-3.0 times higher risks of vegetative dystonia and secondary immune failure.
\end{abstract}

Key words: children, respiratory organs diseases, co-morbid pathology, particulate matter, benzene, phenol, formaldehyde, metals, cohort study.

Over the last decades diseases in the respiratory organs have permanently taken the leading place in the structure of overall incidence among children younger than 14 . This pathology accounts for $45.8-59.4 \%$ among children of various ages [1-3]. In 2017 in the Russian Federation prevalence of the respiratory pathology diagnosed in a child for the first time amounted to $117,449.94$ cases per 100 thousand children. Prevalence of the pathology in 51 RF regions, Perm region included, was higher than in the country on average $^{1}$. Epidemiologic research revealed that technogenic environmental factors exerted adverse impacts on population health; according to the WHO data, each third disease in a child is caused by adverse effects produced by environmental factors [4-7]. Growing emissions from motor transport and industrial enterprises result in greater ambient air contamination in large industrial centers with a mixture of chemicals that contains particulate matter, metals, aromatic hydrocarbons, formaldehyde, and other compounds [8, 9]. Despite some improvements in the ambient air quality detected in recent years, in 2017 in the RF high air contamination levels were detected in 15 regions; the air was predomi-

(C) Maklakova O.A., 2019

Ol'ga A. Maklakova - Head of the Advisory and Polyclinic Department; Associate Professor at Human Ecology and Life Activities Safety Department (e-mail: olga_mcl@fcrisk.ru; tel.: +7 (342) 236-80-984; ORCID: http://orcid.org/0000-00019574-9353).

${ }^{1}$ Incidence among children (aged 0-14) in Russia in 2017: statistical data // the Department for monitoring, analysis, and strategic development of the public healthcare, The RF Public Healthcare Ministry. - M., 2018. - Part V. - p. 143. 
nantly contaminated with heavy metals, phenol, and particulate matter ${ }^{2}$.

According to numerous research works, an adverse ecological situation causes risks of health disorders among children, first of all, in the respiratory organs $[4-7,11-16]$. Incidence with respiratory pathologies tends to be 2.0-4.6 times higher in industrial cities; it is especially true for allergic diseases and secondary immune failures with their prevalence being by 1.5 times higher than in the country on average $[4,6,7,14-17]$. Diseases of the respiratory organs are known to be mostly recurrent under exposure to adverse technogenic chemical factors and they are often combined with various syndromes and diseases [13-16]. When a concomitant pathology occurs, it makes drastic changes in a clinical picture of the main pathologic process and determines nature and gravity of possible complications; all the above mentioned makes it difficult to diagnose and treat a disease and deteriorates a patient's life quality [4, 16-18].

At present there are a lot of vital tasks the preventive medicine is to solve; one of them is to assess risks of co-morbid pathology occurrence in children with chronic diseases in the respiratory organs under aerogenic exposure to technogenic chemicals.

Our research goal was to perform a cohort study in order to assess structure and dynamics of diseases in the respiratory organs and co-morbid pathology occurrence in children who permanently lived on territories where ambient air was contaminated with various technogenic chemicals.

\section{Data and methods}

We performed a two-direction cohort study on children who lived under various combined aerogenic exposure to chemical environmental factors; the basic goal was to reveal peculiarities related to development of diseases in the respiratory organs and comorbid pathology in them. Children were included into our study with random sampling technique; all of them underwent in-patient treatment and regular medical check-ups in 2000-2017 at the Federal Scientific Center for Medical and Preventive Health Risk Management Technologies. We divided the children into three cohorts.

The focus group A was made up of 47 children $(55.3 \%$ boys and $44.7 \%$ girls, their average age was $5.33 \pm 0.35$ at the moment when the study was performed), who were born and permanently lived in an industrial city in Perm region. According to data obtained within social and hygienic monitoring activities performed by the Perm Regional Center for Hygiene and Epidemiology, children from the focus group A lived on a territory where in 2000-2016 maximum single concentrations of particulate matter in the air amounted to 1.62.8 MPC; phenol, 1.5-3.5 MPC: formaldehyde, up to $2.2 \mathrm{MPC}$; benzene, up to 14.7 MPC. Average annual concentrations of phenol amounted to 1.3-2.3 MPC a.a.; particulate matter, 1.1-1.3 MPC a.a.; formaldehyde, 1.4-3.0 MPC a.a. (in 2011-2013).

The focus group $\mathrm{B}$ included 45 children (51.1\% boys and $48.9 \%$ girls, their average age being $5.66 \pm 0.29$ ) who permanently lived in a city in Perm region where a ferrous metallurgy plant was located. Experts from the Perm Regional Center for Hygiene and Epidemiology and the Federal Scientific Center for Medical and Preventive Health Risk Management Technologies assessed ambient air quality within social and hygienic monitoring activities in 2010-2013 and 2015 on a territory where children from the focus group B lived. As a result, they detected concentrations of manganese and vanadium that were higher than MPC (up to 2.19 MPC a.a. and 1.2 MPC a.a. accordingly); particulate matter concentrations were up to $0.6 \mathrm{MPC}$ a.a.

The reference group included 22 children (54.5\% boys and $45.5 \%$ girls, their average age being $5.93 \pm 0.30$ ) who lived on a territory that was sanitary and hygienically safe. All three groups were comparable in terms of sex, age, and social status.

\footnotetext{
${ }^{2}$ On sanitary-epidemiologic welfare of the population in the Russian Federation in 2017: The state report. - M.: The Federal Service for Surveillance over Consumer Rights Protection and Human Well-being, 2018. - P. 268.
} 
Cohort observation period lasted from 4 to 10 years. The second medical examination was accomplished at age $7-10$ on 37 children from the focus group A (their average age was $8.27 \pm 0.32$ at that moment), 38 children from the focus group B (their average age was $8.43 \pm 0.42$ ), and 16 children from the reference group (their average age was $8.67 \pm 0.46$ ). 46 children had the third medical examination when they were 11-14 (16 children from the focus group A, 18 children from the focus group B, and 12 children from the reference group).

Medical and biological research was performed in full conformity with the ethical principles stated in Helsinki Declaration (1975) and the RF State Standard GOST-R 52379-2005². The examination included medical and social questioning; analysis of data from outpatient case histories (the Form No. 122/u); inspections by medical experts (pediatrician, neurologist, otorhinolaryngologist, allergologist-immunologist, and gastroenterologist); laboratory diagnostics (complete blood count, biochemical blood test, and immunoassay); functional and instrumental research techniques (spirography, electrocardiography, heart rate assessment, ultrasound examination of the abdominal cavity organs). All the examinations were conducted according to conventional procedures.

Statistical analysis included conventional techniques of descriptive statistics; we calculated odds ratio (OR), relative risk, and 95\% confidence interval (CI) and evaluated validity of discrepancies as per Pearson $\chi^{2}$ test and Fischer's test. Probability calculated with Student's t-test was taken as a statistical significance level when it was $\mathrm{p} \leq 0.05$ [20].

\section{Research results}

Results of the first medical examination revealed that pre-school children from the focus groups A and B predominantly suffered from allergic diseases in the upper respiratory tracts (J30.0, J30.3, J31.0), which were 1.3 times more frequently detected in them than in children from the reference group $(p=0.05)$ (Table 1).
We revealed that bronchial asthma (J45.0) and recurrent bronchitis (J39.8, J44.8) were 1.7 times more frequently detected in the focus group A, and chronic lymph-proliferative diseases in the nasopharynx (J35.0, J35.1, J35.2, J35.3) were 2.1 times more frequently detected in the focus group B than in the reference group $(p=0.05-0.007)$.

It was detected that when ambient air was contaminated with benzene, phenol, formaldehyde, and particulate matter, it caused 14.6 times higher risk of allergic rhinitis for presschool children $(\mathrm{OR}=14.64 ; \mathrm{CI}=4.24-50.62)$; exposure to adverse aerogenic impacts by metals caused 4.3 higher risks of tonsils and adenoids hypertrophy $(\mathrm{OR}=4.29 ; \mathrm{CI}=1.44-12.75)$, against children living on a territory where an ecological situation corresponded to sanitaryhygienic standards.

Secondary immune failure (D83.9) was diagnosed in $70.2 \%$ children aged $4-6$ in the focus group $\mathrm{A}$ and it was 1.3 times more frequently than in the focus group B, and 1.4 times more frequently than in the reference group $(p=0.06-0.04)$ (Table 2). Disorders in the autonomic nervous system (G90.8) were registered 1.4 times more frequently in children from the focus group B than in those from the reference group $(p=0.05)$. Functional pathologies in the gastrointestinal tract $(\mathrm{K} 30, \mathrm{~K} 83.8, \mathrm{~K} 86.8)$ were detected with the same frequency in pre-school children from the focus groups $\mathrm{A}$ and $\mathrm{B}$ and it was 1.3-1.4 times more frequent than in the reference group $(\mathrm{p}=0.04-0.014)$. Overall, functional disorders in the gastrointestinal tract were 3.3-4.6 times more probable for 4-6-year-old children exposed to the environment contaminated with technogenic chemicals (the focus group $\mathrm{A}$ had $\mathrm{OR}=4.57$; $\mathrm{CI}=1.28-16.32$; the focus group $\mathrm{B}$ had $\mathrm{OR}=3.27$; $\mathrm{CI}=1.00-10.66$ ).

Our research revealed that two thirds of 4-6-year-old children from the focus group A suffering from respiratory organs diseases also had secondary immune failure and it was 1.5 times higher than in the reference group $(p=0.04) .71 .1 \%$ children who were exposed to

${ }^{3}$ GOST R 52379-2005. The RF State Standard. Good Clinical Practice (ICH E6 GCP) [Web-source]. - M.: Standartinform, 2005. - URL: http://docs.cntd.ru/document/1200041147 (date of visit January 26, 2019). 
Table 1

Incidence among children aged 4-6 (the first examination), $\%$

\begin{tabular}{|l|c|c|c|c|c|c|}
\hline \multicolumn{1}{|c|}{ Nosology } & Focus group & Focus group & \multicolumn{2}{|c|}{$\begin{array}{c}\text { Reference } \\
\text { group }\end{array}$} & \multicolumn{2}{|c|}{ Validity of discrepancies } \\
\cline { 6 - 8 } & $\mathrm{A}$ & \multicolumn{2}{|c|}{$p_{1}$} & $p_{2}$ & $p_{3}$ \\
\hline $\begin{array}{l}\text { Chronic tonsillitis, hypertrophy } \\
\text { of tonsils and adenoids } \\
\text { (J35.0, J35.1, J35.2, J35.3) }\end{array}$ & 42.6 & 65.8 & 31.8 & 0.39 & 0.007 & 0.026 \\
\hline $\begin{array}{l}\text { Allergic rhinitis, pollinosis } \\
\text { (J30.0, J30.1, J30.3) }\end{array}$ & 87.2 & 86.8 & 68.2 & 0.05 & 0.05 & 0.96 \\
\hline $\begin{array}{l}\text { Recurrent bronchitis, tracheitis } \\
\text { (J39.8, J44.8) }\end{array}$ & 6.4 & 7.9 & 0 & 0.31 & 0.30 & 0.78 \\
\hline Bronchial asthma (J45.0) & 57.4 & 47.4 & 36.4 & 0.06 & 0.78 & 0.34 \\
\hline $\begin{array}{l}\text { Common variable immunodefi- } \\
\text { ciency (secondary) (D83.9) }\end{array}$ & 70.2 & 52.6 & 50.0 & 0.06 & 0.80 & 0.04 \\
\hline $\begin{array}{l}\text { Disorders of the autonomic } \\
\text { nervous system (G90.8) }\end{array}$ & 61.7 & 71.1 & 54.5 & 0.57 & 0.05 & 0.34 \\
\hline $\begin{array}{l}\text { Functional dyspepsia, biliary } \\
\text { dyskinesia, reactive pancreatitis } \\
\text { (K30, K83.8, K86.8) }\end{array}$ & 88.9 & 85.1 & 63.6 & 0.014 & 0.04 & 0.59 \\
\hline $\begin{array}{l}\text { Chronic gastritis, chronic } \\
\text { gastroduodenitis (K29.5, K29.9) }\end{array}$ & 4.3 & 11.1 & 9.1 & 0.29 & 0.32 & 0.15 \\
\hline
\end{tabular}

Note:

$p_{1}$ is validity of discrepancies between the focus group $\mathrm{A}$ and the reference group;

$p_{2}$ is validity of discrepancies between the focus group $\mathrm{B}$ and the reference group;

$p_{3}$ is validity of discrepancies between the focus group A and the focus group B.

Table 2

Incidence among children aged 7-10 (the second examination), \%

\begin{tabular}{|l|c|c|c|c|c|c|}
\hline \multicolumn{1}{|c|}{ Nosology } & Focus group & Focus group & \multicolumn{2}{|c|}{$\begin{array}{c}\text { Reference } \\
\text { g }\end{array}$} & \multicolumn{3}{|c|}{ Validity of discrepancies } \\
\cline { 6 - 8 } & & B & $p_{1}$ & $p_{2}$ & $p_{3}$ \\
\hline $\begin{array}{l}\text { Chronic tonsillitis, hypertrophy } \\
\text { of tonsils and adenoids } \\
\text { (J35.0, J35.1, J35.2, J35.3) }\end{array}$ & 48.6 & 65.8 & 31.2 & 0.24 & 0.019 & 0.06 \\
\hline $\begin{array}{l}\text { Allergic rhinitis, pollinosis } \\
\text { (J30.0, J30.1, J30.3) }\end{array}$ & 91.9 & 86.8 & 62.5 & 0.01 & 0.043 & 0.23 \\
\hline $\begin{array}{l}\text { Recurrent bronchitis, tracheitis } \\
\text { (J39.8, J44.8) }\end{array}$ & 10.8 & 7.9 & 0 & 0.23 & 0.34 & 0.28 \\
\hline Bronchial asthma (J45.0) & 59.5 & 47.4 & 31.2 & 0.04 & 0.27 & 0.29 \\
\hline $\begin{array}{l}\text { Common variable immunodefi- } \\
\text { ciency (secondary) (D83.9) }\end{array}$ & 72.9 & 52.6 & 50.0 & 0.07 & 0.86 & 0.04 \\
\hline $\begin{array}{l}\text { Disorders of the autonomic } \\
\text { nervous system (G90.8) }\end{array}$ & 67.6 & 71.1 & 56.2 & 0.43 & 0.29 & 0.74 \\
\hline $\begin{array}{l}\text { Functional dyspepsia, biliary } \\
\text { dyskinesia, reactive pancreatitis } \\
\text { K30, K83.8, K86.8) }\end{array}$ & 94.6 & 92.1 & 68.7 & 0.02 & 0.04 & 0.33 \\
\hline $\begin{array}{l}\text { Chronic gastritis, chronic } \\
\text { gastroduodenitis (K29.5, K29.9) }\end{array}$ & 24.3 & 31.6 & 18.7 & 0.26 & 0.18 & 0.48 \\
\hline
\end{tabular}

Note:

$p_{1}$ - is validity of discrepancies between the focus group A and the reference group;

$p_{2}$ - is validity of discrepancies between the focus group B and the reference group;

$p_{3}-$ is validity of discrepancies between the focus group A and the focus group B. 
the air contaminated with metals suffered from respiratory organs diseases combined with vegetative-vascular dystonia and it was 1.4 times higher than in the reference group $(\mathrm{p}=0.05)$. Relative risk of pathologies in the nervous system amounted to 1.86 for children from the focus group B suffering from chronic diseases of the respiratory organs $(\mathrm{RR}=1.86$; 95\% CI: 1.16-2.99).

The second control medical check-up revealed a greater number of respiratory pathologies among children under aerogenic exposure to technogenic chemicals (Table 3). There was still high prevalence of allergic rhinitis on the examined territories, which was 1.4-1.5 times higher among children from the focus groups than among those from the reference group ( $\mathrm{p}=0.043-0.01)$. We detected 6.8 times higher probability of allergic rhinitis among children from the focus group $\mathrm{A}$ $(\mathrm{OR}=6.80 ; \quad \mathrm{CI}=1.44-32.20)$, and 3.9 times higher probability of the disease among children from the focus group $\mathrm{B}(\mathrm{OR}=3.96$; $\mathrm{CI}=0.99-15.77)$. Diseases of the lymphoid tis- sue in the nasopharynx were detected in $2 / 3$ junior school children who were exposed to adverse aerogenic impacts exerted by metals, and the value was 2.1 times statistically significantly higher than in the reference group $(p=0.019)$, and 1.4 times higher than in the focus group A. We detected that chronic lymphproliferative diseases of the nasopharynx were 4.2 times more probable among junior schoolchildren from the focus group $\mathrm{B}(\mathrm{OR}=4.23$; $\mathrm{CI}=1.21-14.79)$.

We noted that prevalence of chronic allergic pathologies in the lower respiratory tracts (J45.0, J39.8, J44.8) was 2.25 times higher on the territory where ambient air was contaminated with benzene, phenol, formaldehyde, and particulate matter (the focus group A), than on the reference territory $(p=0.012)$, and 1.3 times higher than on the territory exposed to contamination with metals (the focus group $B, p=0.08$ ) (Table 2). We detected that junior schoolchildren from the focus group A ran 4.6 times higher risks of bronchial asthma and recurrent bronchitis

Table 3

Incidence among children aged 11-14 (the third examination), \%

\begin{tabular}{|c|c|c|c|c|c|c|}
\hline \multirow{2}{*}{ Nosology } & \multirow{2}{*}{$\begin{array}{c}\text { Focus group } \\
\text { A }\end{array}$} & \multirow{2}{*}{$\begin{array}{c}\text { Focus group } \\
\mathrm{B}\end{array}$} & \multirow{2}{*}{$\begin{array}{l}\text { Reference } \\
\text { group }\end{array}$} & \multicolumn{3}{|c|}{ Validity of discrepancies } \\
\hline & & & & $p_{1}$ & $p_{2}$ & $p_{3}$ \\
\hline $\begin{array}{l}\text { Chronic tonsillitis, hypertrophy } \\
\text { of tonsils and adenoids } \\
(\mathrm{J} 35.0, \mathrm{~J} 35.1, \mathrm{~J} 35.2, \mathrm{~J} 35.3)\end{array}$ & 31.3 & 66.7 & 33.3 & 0.31 & 0.06 & 0.03 \\
\hline $\begin{array}{l}\text { Allergic rhinitis, pollinosis } \\
(\mathrm{J} 30.0, \mathrm{~J} 30.1, \mathrm{~J} 30.3)\end{array}$ & 93.8 & 83.3 & 66.7 & 0.06 & 0.20 & 0.28 \\
\hline $\begin{array}{l}\text { Recurrent bronchitis, tracheitis } \\
(\mathrm{J} 39.8, \mathrm{~J} 44.8)\end{array}$ & 0 & 8.3 & 0 & - & 0.60 & - \\
\hline Bronchial asthma (J45.0) & 62.5 & 58.3 & 50.0 & 0.51 & 0.65 & 0.80 \\
\hline $\begin{array}{l}\text { Common variable immunodefi- } \\
\text { ciency (secondary) (D83.9) }\end{array}$ & 68.7 & 75.0 & 25.0 & 0.02 & 0.007 & 0.68 \\
\hline $\begin{array}{l}\text { Disorders of the autonomic } \\
\text { nervous system (G90.8) }\end{array}$ & 75.0 & 91.7 & 33.3 & 0.03 & 0.001 & 0.12 \\
\hline $\begin{array}{l}\text { Functional dyspepsia, biliary } \\
\text { dyskinesia, reactive pancreatitis } \\
(\mathrm{K} 30, \mathrm{~K} 83.8, \mathrm{~K} 86.8)\end{array}$ & 100.0 & 83.3 & 66.7 & 0.02 & 0.29 & 0.09 \\
\hline $\begin{array}{l}\text { Chronic gastritis, chronic } \\
\text { gastroduodenitis (K29.5, K29.9) }\end{array}$ & 62.5 & 27.8 & 25.0 & 0.05 & 0.86 & 0.04 \\
\hline
\end{tabular}

Note:

$p_{1}$ - is validity of discrepancies between the focus group A and the reference group;

$p_{2}-$ is validity of discrepancies between the focus group B and the reference group;

$p_{3}-$ is validity of discrepancies between the focus group A and the focus group B. 
$(\mathrm{OR}=4.58 ; \quad \mathrm{CI}=1.30-16.18)$ than children from the reference group who lived on a hygienically safe territory. Besides, air contamination with benzene, phenol, formaldehyde, and particulate matter caused 1.4-1.5 more frequent secondary immune failure among children from the focus group A than among those from the focus group $B$ and the reference group ( $p=0.07-0.04)$. We revealed functional pathologies of the gastrointestinal tract in $92.1-94.6 \%$ children aged $7-10$ living on a territory exposed to adverse effects produced by technogenic chemicals and it was $1.3-1.4$ times statistically significantly higher than in the reference group $(p=0.04-0.02)$. Junior schoolchildren who were exposed to adverse impacts by technogenic chemicals ran 5.3-7.9 times higher risks of functional disorders in the gastrointestinal tract (the focus group A: $\mathrm{OR}=7.95 ; \mathrm{CI}=1.35-46.90$; the focus group $\mathrm{B}$ : $\mathrm{OR}=5.30 ; \mathrm{CI}=1.09-25.84)$ than children from the reference group who lived on a hygienically safe territory.

The third check up that was performed on senior schoolchildren revealed that there still was high prevalence of allergic rhinitis under aerogenic exposure to adverse impacts by technogenic chemicals $(93.8-83.3 \%)$ and it was 1.2 times higher than in the reference group (66.7\%, p=0.06-0.20) (Table 4). $2 / 3$ of children aged 11-14 who lived under aerogenic exposure to metals suffered from chronic diseases of the lymphoid tissue in the nasopharynx and it was 2.0-2.1 times higher than in the focus group $\mathrm{A}$ and the reference group $(p=0.06-0.03)$. We noted that secondary immune failure among children from the focus group A aged 11-14 remained practically the same as it had been revealed at the second examination; but there was a 1.4-time growth in its prevalence over 3 years among children from the focus group B. There was a 2.0-time decrease in prevalence of this pathology among children from the reference group, and discrepancies between this group and focus groups A and B became statistically significant $(\mathrm{p}=0.02-0.007)$. We detected that 11-14-yearold children who lived on a territory where the air was contaminated with technogenic chemicals or heavy metals ran 6.6-9.0 times higher risks of secondary immune failure (the focus group $\mathrm{A}$ : $\mathrm{OR}=6.60 ; \mathrm{CI}=1.23-35.44$; the focus group $\mathrm{B}: \mathrm{OR}=9.0 ; \mathrm{CI}=1.42-57.12)$ than children from the reference group.

Over a 6-year-period a number of children with disorders in the autonomic nervous systems grew by $1.2-1.4$ times (Table 4 ), and it was 2.3-2.7 times statistically significantly higher than in the reference group $(p=0.03-0.001)$. We detected that children aged 11-14 who were exposed to ambient air contamination with technogenic chemicals ran 6.0-22.0 times higher risks of disorders in the autonomic nervous system (G90.8) than children from the reference group (the focus group $\mathrm{A}$ : $\mathrm{OR}=6.00 ; \mathrm{CI}=1.15-31.23$; the focus group $\mathrm{B}: \mathrm{OR}=22.0 ; \mathrm{CI}=2.05-236.05$ ). Besides all the children who lived on a territory where ambient air was contaminated with benzene, phenol, formaldehyde, and particulate matter, turned out to have functional pathologies in the gastrointestinal tract, and $2 / 3$ of them suffered from chronic diseases of the upper gastrointestinal tract section (K29.5, K29.9) and it was 1.2-2.5 times statistically significantly higher than in the reference group and the focus group B $(p=0.05-0.02)$. Prevalence of chronic pathologies in the gastrointestinal tract grew by 14.5 times in the focus group A over the total observation period, but it went up only by 2.5-2.7 times in two other groups.

We also detected that senior schoolchildren who suffered from chronic respiratory organs diseases also had secondary immune failure 2.7 times more frequently in the focus group $\mathrm{A}$ and 3.0 times more frequently in the focus group $B$ than in the reference group $(p=0.02-0.007)$. Relative risk of combined chronic respiratory diseases and secondary immune deficiency amounted to 3.0 among children exposed to adverse aerogenic effects produced by metals ( $R R=3.00$; 95\% CI: 1.07-8.43). Number of children who suffered from chronic respiratory pathologies and disorders in the autonomic nervous system and who were ex- 
posed to negative impacts by technogenic chemicals was 2.2 times higher in the focus group A and 2.7 times higher in the focus group B $(p=0.03-0.001)$ than in the reference group. We detected that children who were under aerogenic exposure to metals ran the maximum risk of combined chronic respiratory diseases and vegetative-vascular dystonia which was equal to $2.75(\mathrm{RR}=2.75$; 95\% CI: $1.21-6.23)$.

\section{Conclusions:}

1. Most pre-school children (87.2\%) who were exposed to ambient air contamination with benzene, phenol, formaldehyde, and particulate matter, suffered from allergic rhinitis, and each third child had bronchial asthma and recurrent bronchitis; respiratory organs diseases were combined with immune failure in $2 / 3$ cases. We detected that probability of allergic rhinitis, bronchial asthma, and recurrent bronchitis grew by 4.6-6.8 times over 3-5 years of cohort observations over children by the time they were 7-10 years old. Probability of functional pathologies in the gastrointestinal tract grew by 7.9 times over the same period. By the time children were 11-14 years old, prevalence of chronic diseases in the gastroin- testinal tract grew by 14.5 times, and secondary immune failure and disorders in the autonomic nervous system were diagnosed 6.0-6.6 times more frequently.

2. Each third child aged 4-6 who lived on a territory where ambient air was contaminated with metals (vanadium and manganese) suffered from a chronic disease of the lymphoid tissue in the nasopharynx, and $3 / 4$ of such children had disorders in the autonomic nervous system and ran 1.9 times higher risk of combined respiratory diseases and nervous system pathologies. Probability of allergic rhinitis and pathologies of the lymphoid tissues in the nasopharynx was 3.9-4.2 times higher among junior schoolchildren; probability of functional disorders in the digestive organs, 5.3 times higher. Senior schoolchildren who suffered from chronic respiratory organs diseases ran 2.7-3.0 times higher risk of disorders in the autonomic nervous system and secondary immune failure.

Funding. The research was not granted any sponsor support.

Conflict of interests. The authors state there is no any conflict of interest.

\section{References}

1. Baranov A.A., Il'in A.G. Main trends in children's health dynamics in the Russian Federation. Search for problem solutions. Vestnik Rossiiskoi akademii meditsinskikh nauk, 2011, no. 6, pp. 12-18 (in Russian).

2. Omarova M.N., Kenzhebaeva A.T., Zhumagulova A.N., Aspetov D.R., Zhumatova B.Kh. Respiratory diseases spread among the population of large industrial city. Mezhdunarodnyi zhurnal prikladnykh i fundamental'nykh issledovanii, 2016, no. 12, pp. 828-831 (in Russian).

3. Modestov A.A., Sokovich O.G., Terletskaya R.N. Contemporary tendencies of respiration disease children's morbidity in Russian Federation. Sibirskoe meditsinskoe obozrenie, 2008, no. 6, pp. 3-8 (in Russian).

4. Gigienicheskie aspekty narusheniya zdorov'ya detei pri vozdeistvii khimicheskikh faktorov sredy obitaniya [Hygienic aspects of the impairment of children's health when exposed to chemical environmental factors]. In: N.V. Zaitseva ed. Perm', Knizhnyi format Publ., 2011, 489 p. (in Russian).

5. Korochkina Yu.V., Perekusikhin M.V., Vasil'ev V.V., Panteleev G.V. Hygienic environmental assessment and health of children in Penza. Health Risk Analysis, 2015, no. 3, pp. 33-39. DOI: 10.21668/health.risk/2015.3.05.eng

6. Sly P.D., Kusel M., Franklin P., Holt P.G. Environmental Factors in Children's Asthma and Respiratory Effects. Encyclopedia of Environmental Health, 2011, pp. 367-379.

7. Peden D.B. The epidemiology and genetics of asthma risk associated with air pollution. Journal of Allergy and Clinical Immunology, 2005, no. 115, p. 220.

8. Lezhnin V.L., Kon'shina L.G., Sergeeva M.V. Assessment of children's health risk posed by traffic-related air pollution as exemplified by the city of Salekhard. Gigiena i sanitariya, 2014, no. 1, pp. 8386 (in Russian). 
9. Ushakov A.A., Turbinskii V.V., Pashchenko I.G., Katunina A.S. Hygienic assessment of habitat adverse social and sanitary factors in the Altai Krai. Health Risk Analysis, 2015, no. 4, pp. 50-61. DOI: 10.21668/health.risk/2015.4.07.eng

10. Zhang K., Batterman S. Air pollution and health risks due to vehicle traffic. Science of The Total Environment, 2013, no. 450-451, pp. 307-316.

11. Addendum to the toxicological profile for formaldehyde. Atlanta: Agency for Toxic Substances and Disease Registry, Division of Toxicology and Environmental Medicine, 2010, 149 p.

12. Toxicological profile for phenol. U.S. Department of health and human services, Public Health Service Agency for Toxic Substances and Disease Registry, 2008, 268 p.

13. Troshina V.V., Namazova-Baranova L.S., Tarakanova S.Yu., Zokirov N.Z., Gladkikh V.D., Los' S.P. Epidemiological researches in practice of ecological pediatrics. Izvestiya Samarskogo nauchnogo tsentra Rossiiskoi akademii nauk, 2014, vol. 16, no. 5 (2), pp. 745-749 (in Russian).

14. Maklakova O.A., Ustinova O.Yu., Belyaeva E.S., Shcherbakov A.A. Features of cardiac disorders in children with chronic respiratory diseases associated with aerogenic exposure to chemical environmental factors. Health Risk Analysis, 2016, no. 1, pp. 42-48. DOI: 10.21668/health.risk/2016.1.05.eng

15. Maklakova O.A., Ustinova O.Yu., Alekseeva A.V. Age structure and dynamics of the morbidity rate of respiratory and autonomous nervous system diseases in children living in conditions of the aerogenous impact of chemical factors of technogenic origin (cohort study). Gigiena i sanitariya, 2017, no. 1, pp. 75-78 (in Russian).

16. Nuriakhmetova A.Zh., Faizullina R.M. Clinical and anamnestic features in children with recurrent and chronic respiratory diseases in the industrial region. Meditsinskii vestnik Bashkortostana, 2013, no. 3, pp. 67-71 (in Russian).

17. Kholmatova K.K., Khar'kova O.A., Grzhibovskii A.M. Cohort studies in medicine and public health. Ekologiya cheloveka, 2016, no. 4, 56-64 (in Russian).

18. Fletcher R., Fletcher S., Vagner E. Klinicheskaya epidemiologiya. Osnovy dokazatel'noi meditsiny [Clinical epidemiology. Basics of evidential medicine]. Moscow, Media Sfera, 1998, 352 p. (in Russian).

Maklakova O.A. Assessing risks of respiratory organs diseases and co-morbid pathology in children caused by ambient air contamination with technogenic chemicals (cohort study). Health Risk Analysis, 2019, no. 2, pp. 56-63. DOI: 10.21668/health.risk/2019.2.06.eng

Received: 07.02.2019

Accepted: 25.05.2019

Published: 30.06.2019 